\title{
PENGELOLAAN PENDIDIKAN INKLUSIF DI MADRASAH
}

\section{MANAGEMENT OF INCLUSIVE EDUCATION IN MADRASA}

\author{
Sumarni \\ Pusat Penelitian dan Pengembangan Kementerian Agama RI. \\ Jl. M.H. Thamrin No. 6, Jakarta Pusat \\ email: marni_ch@yahoo.com.au
}

Naskah Diterima: 15 Juli 2019; Direvisi: 28 Juli 2019; Disetujui: 05 Agustus 2019

\begin{abstract}
This study aims to determine how the management of inclusive education in MTs Yabika Tangerang, Banten, especially related to the management of learners, facilities, educators, curriculum and assessment, financing, development, and monitoring and evaluation and its relationship to society. This research uses a qualitative approach. The research informants were the foundation's management, Head and deputy head of MTs Yabika, Head of MA Yabika, teacher, and Head of Administration. Data analysis uses descriptive qualitative techniques. The results showed that the management of inclusive education in MTs Yabika in general was running quite well. Madrasas try to meet the needs of SNC in accordance with their abilities both infrastructure, facilities, curriculum, learning and assessment system. Madrasas have also provided special tutors for SNC. However, there are several aspects of the management of inclusive education that have not been running as it should. Acceptance of new SNC did not go through the assessment process and identification according to standards but only using tests and interviews with parents of students; many teachers have not received training for handling SNC. There is also no guidance, supervision and evaluation from supervisors and the Ministry of Religion. Likewise, cooperation with external parties has not been done much by MTs Yabika.
\end{abstract}

Keywords: Madrasa; Management; Inclusive education

\begin{abstract}
Abstrak
Penelitian ini bertujuan untuk mengetahui bagaimana pengelolaan pendidikan inklusif di MTs Yabika Tangerang Banten khususnya terkait pengelolaan peserta didik, sarana prasarana, tenaga pendidik, kurikulum dan penilaian, pembiayaan, pembinaaan, dan monitoring dan evaluasi serta hubungannya dengan masyarakat. Penelitian ini menggunakan pendekatan kualitatif. Informan penelitian adalah pengurus yayasan, Kepala dan wakil kepala MTs Yabika, Kepala MA Yabika, guru, dan Kepala Tata Usaha. Analisis data menggunakan teknik deskriptif kualitatif. Hasil penelitian menunjukkan bahwa pengelolaan pendidikan inklusif di MTs Yabika secara umum sudah berjalan dengan cukup baik. Madrasah berusaha memenuhi kebutuhan ABK sesuai dengan kemampuannya baik sarana prasarana, fasilitas, kurikulum, pembelajarannya maupun sistem penilaiannya. Madrasah juga sudah menyediakan guru pembimbing khusus bagi ABK. Namun ada beberapa aspek dalam pengelolaan pendidikan inklusif yang belum berjalan sebagaimana mestinya. Penerimaan ABK baru tidak melalui proses asesmen dan identifikasi sesuai standar tetapi hanya menggunakan tes dan wawancara dengan orang tua siswa; banyak guru yang belum mendapatkan pelatihan untuk penanganan ABK. Pembinaan, pengawasan dan evaluasi dari pengawas dan Kemenag juga tidak ada. Demikian juga kerjasama dengan pihak eksternal juga belum banyak dilakukan oleh MTs Yabika.
\end{abstract}

Kata Kunci: Madrasah; Pengelolaan; Pendidikan inklusif 


\section{PENDAHULUAN}

Setiap warga negara dijamin dan mempunyai hak yang sama untuk memperoleh pendidikan yang bermutu, tidak terkecuali bagi warga negara yang memiliki kelainan fisik, emosional, mental dan sosial. Karena itu negara memiliki kewajiban untuk memberikan pelayanan pendidikan yang bermutu kepada setiap warganya tanpa terkecuali termasuk mereka yang memiliki perbedaan dalam kemampuan (difabel). Hal ini tertuang dalam Undang-Undang Dasar 1945 pasal 31 ayat 1 yang menyatakan bahwa setiap warga negara mempunyai kesempatan yang sama memperoleh pendidikan. Bagi Anak Berkebutuhan Khusus (ABK), kesempatan mereka untuk memperoleh pendidikan juga telah diatur dalam Undang-Undang Nomor 20 tahun 2003 tentang Sistem Pendidikan Nasional pasal 32 ayat 1 yang menyebutkan bahwa pendidikan khusus merupakan pendidikan bagi peserta didik yang memiliki tingkat kesulitan dalam mengikuti proses pembelajaran karena kelainan fisik, emosional, mental, sosial, dan/atau memiliki potensi kecerdasan dan bakat istimewa.

Upaya pemerintah untuk memberikan layanan pendidikan bagi $\mathrm{ABK}$ juga telah dituangkan melalui Peraturan Pemerintah (PP) Nomor 72 tahun 1991 tentang pendidikan luar biasa, Permendiknas Nomor 70 tahun 2009 tentang pendidikan inklusif bagi peserta didik yang memiliki kelainan dan memiliki potensi kecerdasan dan/atau bakat istimewa, serta Surat Edaran Dirjen Manajemen Pendidikan Dasar dan Menengah Kemendiknas Nomor 380/C.C6/MN/2003, tanggal 20 Januari 2003, yakni setiap kabupaten/kota diwajibkan menyelenggarakan dan mengembangkan pendidikan inklusif di sekurang-kurangnya 4 sekolah yang terdiri dari SD, SMP, SMA, dan SMK.

Saat ini sudah banyak lembaga pendidikan yang mengembangkan pendidikan inklusif, mengingat cukup banyaknya jumlah ABK khusus di Indonesia. Terdapat 32 ribu sekolah reguler yang menjadi sekolah inklusi diberbagai daerah. Data Badan Pusat Statistik (BPS) menunjukkan bahwa dari 1,6 juta ABK di Indonesia, baru $18 \%$ yang sudah mendapatkan layanan pendidikan inklusif.
Sekitar 115 ribu ABK bersekolah di Sekolah Luar Biasa (SLB), sedangkan ABK yang bersekolah di sekolah regular pelaksana sekolah inklusif berjumlah sekitar 299 ribu (Mi'raj Islamic News Agency (MINA), 2017). Masih rendahnya jumlah $\mathrm{ABK}$ yang mendapatkan layanan ini disebabkan oleh berbagai faktor diantaranya anak yang tidak ingin bersekolah, orang tua yang kurang mendukung pendidikan bagi anaknya, akses sekolah yang cukup jauh dari tempat tinggal $\mathrm{ABK}$, dan lain sebagainya.

Kementerian Agama sudah sepantasnya turut dalam pengembangan pendidikan inklusif. Peraturan Menteri Agama (PMA) Nomor 90 Tahun 2013 tentang Penyelenggaraan Pendidikan Madrasah menyebutkan bahwa madrasah wajib menyediakan akses bagi peserta didik berkebutuhan khusus. Melalui Direktorat Pendidikan Madrasah, Kementerian Agama bertekad mengembangkan pendidikan untuk anak berkebutuhan khusus (difabelitas) atau dikenal dengan pendidikan inklusif. Pada tahun 2015, madrasah mulai mencoba menyelenggarakan pendidikan inklusif dengan bantuan Australian Agency for International Development (AusAID).

Banten merupakan salah satu propinsi yang menjadi pilot project dalam pengembangan pendidikan inklusif di madrasah. Di propinsi ini terdapat 86 lembaga sekolah untuk ABK yang terdiri dari 7 SLB negeri dan 79 SLB swasta. Jumlah siswa berkebutuhan khusus sebanyak 38 ribu dan hanya 4 ribu yang terlayani $(10,52 \%)$. Untuk pendidikan inklusif, terdapat 53 SD dan 4 SMP yang melayani $\mathrm{ABK}$ yang tersebar pada 4 kabupaten/kota di Propinsi Banten (Tangsel Pos, 2016). Data madrasah inklusif secara formal belum ada, walaupun sudah ada beberapa madrasah yang sudah menerima ABK. Pada tahun 2015 Kantor Wilayah (Kanwil) Kementerian Agama Provinsi Banten melalui Pusat Pengembangan Madrasah atau Madrasah Development Center bekerjasama dengan AusAID melakukan program pengembangan model madrasah inklusif. Sebanyak 4 madrasah yang menjadi pilot project. MTs Yabika Tangerang merupakan salah satu madrasah yang ditunjuk untuk 
pengembangan pilot project madrasah inklusi di propinsi ini. Penunjukkan tersebut didasarkan pada banyaknya jumlah siswa berkebutuhan khusus, dan juga selama ini pihak madrasah berkomitmen untuk menerapkan pendidikan inklusif, sehingga siswa berkebutuhan khusus mendapat hak dan perlindungan yang sama dari para pengajar dan pihak sekolah. Madrasah ini diharapkan menjadi salah satu barometer keberhasilan model pendidikan inklusif di madrasah. Sampai saat ini belum ada penelitian bagaimana pengelolaan pendidikan inklusif pada madrasah tersebut. Penelitian ini mengkaji bagaimana pengelolaan pendidikan inklusif di MTs Yabika Tangerang Banten. Tujuan penelitian ini adalah untuk mengetahui bagaimana pengelolaan pendidikan inklusif di MTs Yabika. Hasil penelitian ini diharapkan dapat memperoleh data empirik tentang pengelolaan pendidikan inklusif di madrasah.

\section{Kajian Teori}

\section{Pengertian Pengelolaan}

Pengelolaan sama artinya dengan manajemen, dimana kata manajemen berasal dari bahasa Inggris, yaitu management yang berarti ketatalaksanaan, tata pimpinan, pengelolaan (Djamarah and Zain, 2006). Menurut Kamus Besar Bahasa Indonesia, kata pengelolaan mempunyai 4 pengertian, yaitu: pengelolaan adalah proses atau cara perbuatan mengelola; pengelolaan adalah proses melakukan kegiatan tertentu dengan menggerakkan tenaga orang lain; pengelolaan adalah proses yang membantu merumuskan kebijakan dan tujuan organisasi; pengelolaan adalah proses yang memberikan pengawasan pada semua hal yang terlibat dalam pelaksanaan kebijakan dan pencapaian tujuan. Pengelolaan adalah subtantif dari mengelola, sedangkan mengelola berarti suatu tindakan yang dimulai dari penyususnan data, merencana, mengorganisasikan, melaksanakan, sampai dengan pengawasan dan penilaian. Dari uraian di atas dapat disimpulkan bahwa pengelolaan (manajemen) merupakan suatu cara atau proses mulai dari perencanaan, pengorganisasian, pengarahan, dan pengawasan semua sumber daya organisasi untuk mencapai tujuan yang telah ditetapkan.

\section{Pendidikan Inklusif}

Pendidikan inklusif adalah sistem layanan pendidikan yang memberikan kesempatan kepada semua anak belajar bersama-sama di sekolah umum dengan memperhatikan keragaman dan kebutuhan individual, sehingga potensi anak dapat berkembang secara optimal (Direktorat Pembinaan Sekolah Luar Biasa, 2008). Pendidikan inklusif sebagai tindakan hadir di kelas pendidikan reguler dengan dukungan dan layanan diperlukan untuk berhasil mencapai tujuan pendidikan (Dianne Tirocci dan Brandy Reese dalam Garnida, 2015). Penyertaan dalam lingkungan skolastik menguntungkan kedua penyandang cacat siswa dan siswa noncacat dalam memperoleh kehidupan yang lebih baik, dengan memasukkan semua siswa sebanyak mungkin dalam kelas pendidikan umum atau umum yang dapat dipelajari semua siswa untuk bekerja secara kooperatif, belajar untuk bekerja dengan berbagai jenis orang, dan belajar bagaimana membantu orang dalam tugas. Definisi ini menunjukkan bahwa keberadaan $\mathrm{ABK}$ di kelas regular merupakan sesuatu yang penting untuk mencapai tujuan pembelajaran di kelas. Keberadaan ABK di kelas inklusif bermanfaat bagi semua anak, khususnya dalam pengembangan kompetensi sosial dan peningkatan kecakapan hidup. Hal ini dapat terwujud manakala $\mathrm{ABK}$ bekerja sama secara sinergis dengan anak-anak lainnya dalam menyelesaikan tugas-tugas akademik di sekolah.

Menurut Permendiknas Nomor 70 Tahun 2009 tentang pendidikan inklusif bagi peserta didik yang memiliki kelainan dan memiliki potensi kecerdasan dan/atau bakat istimewa, pasal 1 disebutkan bahwa pendidikan inklusif adalah sistem penyelenggaraan pendidikan yang memberikan kesempatan kepada semua peserta didik yang memiliki kelainan dan memiliki potensi kecerdasan dan/atau bakat istimewa untuk mengikuti pendidikan atau pembelajaran dalam lingkungan pendidikan secara bersama-sama dengan peserta didik pada umumnya. Pengertian pendidikan inklusif sejalan dengan Permendiknas Tahun 2008 tentang Standar Kualifikasi Akademik dan Kompetensi Guru Pendidikan Khusus, bahwa pendidikan inklusif adalah pendidikan yang 
memberikan kesempatan bagi peserta didik berkebutuhan khusus karena kelainan fisik, emosional, mental, intelektual, sosial, dan memiliki potensi kecerdasan dan/atau bakat istimewa untuk belajar bersama-sama dengan peserta didik lain pada satuan pendidikan umum dan satuan pendidikan kejuruan, dengan cara menyediakan sarana dan prasarana, pendidik, tenaga kependidikan dan kurikulum yang disesuaikan dengan kebutuhan individual peserta didik. Intinya, pendidikan inklusif merupakan bentuk layanan pendidikan bagi ABK di sekolah umum/madrasah dengan menyediakan berbagai fasilitas pembelajaran yang dibutuhkan oleh ABK.

Pada tataran mikro, manajemen pendidikan inklusif diartikan sebagai upaya untuk mengelola sumber daya pendidikan untuk mewujudkan suasana belajar dan proses pembelajaran yang kondusif agar peserta didik dapat menunjukkan potensinya secara optimal (Garnida, 2015). Manajemen pendidikan inklusif merupakan proses pengaturan dan pengelolaan sumber daya yang terkait dengan penyelenggaraan pendidikan inklusif yang meliputi komponen-komponen pendidikan inklusi yaitu manajemen kesiswaan, manajemen kurikulum dan penilaian, manajemen tenaga pendidik, manajemen sarana prasarana, manajemen keuangan, manajemen lingkungan (internal dan eksternal), manajemen layanan khusus, dan monitoring dan evaluasi penyelenggara pendidikan inklusif.

Manajemen Kesiswaan. Langkah awal untuk menandai anak-anak yang mengalami kelainan atau anak dengan kebutuhan khusus adalah dengan melakukan identifikasi dan assesmen tehadap peserta didik baru. Identifikasi merupakan proses untuk menemukan dan mengenali keberagaman anak/peserta didik. Pada tahap identifikasi, kita belum sampai menjawab hal-hal yang terkait dengan tantangan dan potensi dari peserta didik (Arikunto, 1988). Kegiatan identifikasi ini dilakukan untuk memahami adanya keberagaman pada peserta didik dengan cara menemukenali peserta didik berdasarkan ciriciri yang ada. Kegiatan identifikasi ini diberlakukan pada peserta didik baru dan peserta didik yang sudah melaksanakan pembelajaran. Identifikasi dilakukan pada proses Penerimaan Peserta Didik Baru (PDBK) atau menjelang proses Kegiatan Belajar Mengajar (KBM)

Teknik pelaksanaan identifikasi PDBK ini adalah dengan pengamatan (observasi); wawancara (interview) pada anak bersangkutan, pendampingnya, dan orangtuanya; dan dokumentasi yakni dokumen yang berupa hasil pemeriksaan psikolog, surat keterangan dokter, psikiater, atau ahli lainnya. Alat identifikasi yang digunakan dapat berupa lembar checklist atau panduan pengamatan, panduan wawancara atau angket. Kegiatan identifikasi ini dapat dilakukan oleh kepala madrasah; guru kelas dan guru mata pelajaran; Guru Pembimbing Khusus (GPK) dan guru bimbingan dan konseling (BK); orangtua; dan tenaga profesional (dokter, psikiater, psikolog, pekerja sosial, dan terapis) apabila dibutuhkan.

Upaya untuk mencermati lebih jauh tentang latar belakang, potensi, dan kondisi khusus pada siswa adalah dengan melakukan asesmen. Asesmen pendidikan adalah usaha atau proses untuk mendapatkan informasi mengenai kelebihan, kekurangan, dan kebutuhan peserta didik dengan berbagai alat dan teknik. Asesmen ini bermanfaat untuk penentuan (determining eligibility); perencanaan pembelajaran (program planning); memonitor kemajuan peserta didik (monitoring student programme); dan evaluasi program (evaluation of program). Sasaran kegiatan asessmen ini antara lain peserta didik berkebutuhan khusus di madrasah dan peserta didik berkebutuhan khusus yang akan ke madrasah. Asesmen ini bisa dilakukan oleh GPK; guru kelas; guru mata pelajaran; guru BK; dan tenaga profesional terkait. Hasil identifikasi dan asesmen akan dipergunakan sebagai dasar dari pengembangan profil peserta didik.

Manajemen Kurikulum dan Penilaian. Kurikulum pada penyelenggara pendidikan inklusif harus mencakup kurikulum nasional yang merupakan standar nasional yang dikembangkan oleh Kementerian Pendidikan dan Kebudayaan. Kurikulum yang digunakan di kelas inklusif adalah kurikulum anak normal (reguler) yang disesuaikan (dimodifikasi) dengan kemampuan awal dan karakteristik siswa. Dalam pembelajaran inklusif, model 
kurikulum bagi siswa berkebutuhan khusus dikelompokkan menjadi empat, yaitu: (1) duplikasi kurikulum, yaitu siswa berkebutuhan khusus menggunakan kurikulum yang tingkat kesulitannya sama dengan siswa rata-rata atau reguler, (2) modifikasi kurikulum, yaitu kurikulum siswa rata-rata atau reguler disesuaikan dengan kebutuhan dan kemampuan atau potensi siswa berkebutuhan khusus, (3) substitusi kurikulum, yaitu beberapa bagian kurikulum siswa rata-rata ditiadakan dan diganti dengan yang kurang lebih setara, (4) omisi kurikulum, yaitu bagian dari kurikulum umum untuk mata pelajaran tertentu ditiadakan total, karena tidak memungkinkan bagi siswa berkebutuhan khusus untuk dapat berfikir setara dengan anak rata-rata (Tarmansyah, 2007). Sedangkan Penilaian adalah proses pengumpulan dan pengolahan informasi untuk mengukur pencapaian prestasi belajar peserta didik. Penilaian hasil belajar bagi peserta didik berkebutuhan khusus perlu adanya penyesuaian dengan jenis hambatan peserta didik. Penyesuaian tersebut meliputi: (1) Penyesuaian waktu, (2) Penyesuaian cara, dan (3) Penyesuaian Materi/isi (Kustawan, 2013).

\section{Manajemen Tenaga Pendidik.}

Pendidik atau guru yang terlibat di sekolah inklusif yaitu guru kelas, guru mata pelajaran, dan guru pembimbing khusus. Guru pembimbing khusus adalah guru yang mempunyai latar pendidikan khusus (pendidikan luar biasa) atau guru yang pernah mendapat pelatihan tentang pendidikan khusus (luar biasa), yang ditugaskan di sekolah inklusif. Seorang guru harus memiliki empat kompetensi dasar guru, yaitu kompetensi pedagogis, profesional, kepribadian, dan sosial. Kompetensi guru inklusif selain dilandasi oleh empat kompetensi utama, secara khusus juga berorientasi pada tiga kemampuan utama lain, yaitu kemampuan umum (ability), kemampuan dasar (basic ability), dan kemampuan khusus (specific ability). Guru inklusif harus memiliki kompetensi untuk mendidik siswa berkebutuhan khusus, dan untuk mendidik peserta didik berkebutuhan khusus jenis tertentu dalam bentuk: a) menyusun instrumen penilaian pendidikan khusus, b) melaksanakan pendampingan untuk pendidikan kebutuhan khusus, c) memberikan bantuan layanan khusus, d) memberikan bimbingan secara berkesinambungan untuk siswa berkebutuhan khusus, e) memberikan bantuan kepada siswa berkebutuhan khusus (Mudjito, Harizal and Elfindri, 2012).

Manajemen Sarana Prasarana. Sarana dan prasarana merupakan salah satu komponen penting dalam penyelenggaraan pendidikan. Dalam penyelenggaraan pendidikan inklusif sarana prasarana yang dibutuhkan akan lebih bervariasi, karena siswa berkebutuhan khusus juga memerlukan beberapa sarana prasarana khusus penunjang proses pembelajaran, yang menyesuaikan dengan jenis kebutuhan khusus siswa. Sekolah inklusif harus menyediakan sarana dan prasarana yang menunjang bagi siswa berkebutuhan khusus, misalnya bukubuku pelajaran dalam bentuk braille, buku audio atau talking-books untuk siswa tunanetra, dan peralatan khusus yang sesuai dengan kondisi dan kebutuhan siswa berkebutuhan khusus. Selain sarana prasarana yang menunjang, perlu adanya akomodasi yang layak dan aksesibilitas bagi ABK. Akomodasi yang layak dan aksesibilitas yang dapat diberikan oleh sekolah berdasarkan hasil identifikasi dan asesmen peserta didik dengan disablitas. Menurut Undang-Undang Nomor 8 Tahun 2016 tentang Penyandang Disabilitas, akomodasi yang layak adalah modifikasi dan penyesuaian yang tepat dan diperlukan untuk menjamin penikmatan atau pelaksanaan semua hak asasi manusia dan kebebasan fundamental untuk penyandang disabilitas berdasarkan kesetaraan, sedangkan aksesibilitas adalah kemudahan yang disediakan untuk penyandang disabilitas guna mewujudkan kesamaan kesempatan.

\section{Manajemen}

Keuangan/Dana.

Pendanaan dalam penyelenggaraan pendidikan inklusif dapat diperoleh dari berbagai sumber seperti pemerintah, pemerintah daerah, swsata, Non Governemnt Organization (NGO), masyarakat (orang tua peserta didik dan lembaga swadaya masyarakat), dan/atau dana dari luar negeri (Garnida, 2015). Manajemen keuangan pada sekolah inklusif harus mengalokasikan sebagian dananya untuk berbagai keperluan khusus, seperti penilaian, modifikasi kurikulum, media, metode dan insentif bagi tenaga ahli yang terlibat. Sebab pada dasarnya kelas inklusif memiliki 
perbedaan dengan kelas reguler, baik dari segi fasilitas, guru, maupun materi. Oleh karena itu, kebutuhan dana sekolah inklusif akan lebih besar daripada sekolah reguler. Sekolah harus betul-betul mempersiapkan segala kebutuhan pendidikan inklusif agar pelayanan yang diberikan pada siswa dapat optimal.

Manajemen Lingkungan (internal dan eksternal). Masyarakat selaku mitra sekolah penyelenggara pendidikan inklusif memiliki peran yang strategis dalam penyelenggaraan pendidikan inklusif dan pembangunan pendidikan, baik sebagai pelaku, penyelenggara, pengelola, penyandang dana, pengawas maupun tenaga kependidikan. Sekolah perlu melakukan suatu upaya untuk dapat menarik perhatian masyarakat (luar dan dalam) dan para stakeholder agar mau turut serta berpartisipasi dan bekerja sama dalam penyelenggaraan pendidikan inklusif.

Manajemen Layanan Khusus. Manajemen layanan khusus merupakan suatu proses kegiatan yang memberikan pelayanan kebutuhan kepada siswa untuk menunjang kegiatan pembelajaran agar tujuan pendidikan bisa tercapai secara efektif dan efisien. Manajemen layanan khusus yang diberikan oleh sekolah meliputi berbagai kegiatan dan fasilitas seperti bimbingan dan konseling, perpustakaan, usaha kesehatan sekolah, ekstrakurikuler, koperasi, kantin, dan kelas inklusif.

\section{Monitoring dan Evaluasi Penyelenggara Pendidikan Inklusif.} Monitoring dan evaluasi adalah suatu kegiatan yang ditujukan pada suatu kegiatan atau program dalam hal ini penyelenggaraan pendidikan inklusif yang sedang atau sudah berlangsung. Monitoring merupakan aktivitas atau kegiatan yang dilakukan oleh kepala sekolah untuk melihat atau memantau jalannya penyelenggaraan pendidikan inklusif selama kegiatan berlangsung, dan menilai ketercapaian tujuan, melihat faktor pendukung dan penghambat program penyelenggaraan pendidikan inklusif di sekolahnya. Sedangkan evaluasi merupakan suatu proses sistematis dalam mengumpulkan, menganalisis, dan menginterpretasikan informasi untuk mengetahui tingkat keberhasilan pendidikan inklusif dengan kriteria tertentu yang telah ditetapkan untuk pengambilan suatu keputusan (Kustawan, 2013).

Selain kepala sekolah, pengawas memiliki peran yang signifikan dan strategis dalam proses dan hasil pendidikan yang bermutu di sekolah. Dalam konteks ini peran pengawas sekolah meliputi pemantauan, supervisi, evaluasi, pelaporan dan tindak lanjut pengawas yang harus dilakukan secara teratur dan berkesinambungan (PP 19 Tahun 2005, pasal 55). Peran pengawas setidaknya sebagai teladan bagi sekolah dan sebagai rekan kerja yang serasi dengan pihak sekolah dalam memajukan sekolah binaan. Pada sekolah penyelenggara pendidikan inklusif, seorang pengawas mempunyai tanggung jawab untuk mengawasi jalannya semua program sekolah dan mengontrol jalannya pelaksanaan pendidikan inklusif dalam setiap program dan kegiatan yang dilaksanakan oleh sekolah.

\section{Kerjasama dengan pihak lain}

Sekolah penyelenggara pendidikan inklusif perlu melakukan kerjasama baik dengan baik internal maupun eksternal. Kerjasama internal dilakukan dengan semua komponen-komponen yang ada di sekolah seperti kepala sekolah, guru, sisa, orang tua siswa, pengawas, dll. Sedangkan kerjasama dengan pihak luar dapat melibatkan pihak lain seperti SLB, Pusat sumber pendidikan inklusif, rumah sakit, klinik, pusat terapi atau pusat intervensi, Perguruan Tinggi, atau lembagalembaga lainnya yang memiliki program penyelenggaraan, pembinaan, dan pengembangan keilimuan yang sama.

\section{Madrasah}

Secara etimologi, kata madrasah dalam Kamus Besar Bahasa Indonesia adalah sekolah atau perguruan yang biasanya berdasarkan Agama Islam (Departemen Pendidikan dan Kebudayaan, 1994). Sedangkan di dalam Ensiklopedi Islam di Indonesia, kata madrasah adalah kata yang berasal dari bahasa Arab, dari kata dasar "darasa" yang artinya "belajar". Madrasah berarti tempat untuk belajar. Penelitian ini fokus pada Madrasah Tsanawiyah, jenjang dasar pada pendidikan formal di Indonesia, setara dengan Sekolah Menengah Pertama (SMP) yang 
pengelolaannya dilakukan oleh Kementerian Agama. Pendidikan madrasah tsanawiyah ditempuh dalam waktu 3 tahun, mulai dari kelas 7 sampai 9.

\section{Penelitian Terdahulu}

Pendidikan inklusif sudah lama menjadi isu yang penting karena pendidikan ini memberikan kesempatan atau hak yang sama bagi semua warga negara terutama untuk anak yang memiliki kebutuhan khusus. Madrasah secara khusus belum mengatur masalah penyelenggaraan pendidikan inklusif ini. Hasil penelitian kebijakan pendidikan inklusif di Kementerian Agama (Kemenag) belum menjadi priorotas karena secara legal Kemenag belum memiliki dasar hukum yang pasti mengenai pendidikan inklusif di madrasah, sehingga pihak-pihak bidang pendidikan madrasah kemenag DIY memandang bahwa pendidikan inklusif belum menjadi hal yang urgent direalisasikan di madrasah (Sholikhah, 2016).

Penelitian lain tentang evaluasi pelakasanaan program pendidikan inklusif di Madrasah Aliyah Negeri Maguwoharjo Yogyakarta menunjukkan bahwa (a) evalusi contex menunjukkan program pendidikan inklusif telah memiliki landasan kebijakan yang jelas dan memiliki tujuan program yang relevan, (b) evaluasi input menunjukkan karakteristik $\mathrm{ABK}$ terdiri dari siswa $\mathrm{ABK}$ tunanetra dan tunadaksa, Guru Pembimbing Khusus (GPK) berlatar belakang pendidikan S1 pendidikan luar biasa dan telah menjalankan fungsinya dengan baik. Belum semua guru mengikuti pelatihan tentang pendidikan inklusif. Sarana prasarana berupa aksesibilitas fisik belum optimal. Kurikulum yang digunakan merupakan KTSP yang berlaku untuk semua siswa. Pembiayaan program belum memiliki anggaran khusus penyelenggaraan pendidikan inklusif, (c) evaluasi process menunjukkan bahwa dalam proses pengelolaan telah memiliki manajer inklusif, dan memiliki jaringan dengan stakeholder, proses pembelajaran telah sesuai dengan kurikulum perlu pengembangan media bagi siswa berkebutuhan khusus, (d) evaluasi product menunjukkan siswa $\mathrm{ABK}$ mampu mencapai prestasi akademik dan non akademik yang membanggakan (Suryati and Haryanto, 2016).

Puslitbang Pendidikan Agama dan Keagamaan tahun 2017 juga sudah melakukan penelitian tentang pendidikan inklusif ini. Penelitian ini bertajuk "Madrasah Pada Setting Daerah Khusus". Penelitian ini dilakukan di MTs Yaketunis Yogyakarta. MTs ini merupakan salah satu madrasah yang menyelenggarakan pendidikan inklusif. Hasil penelitian ini menunjukkan bahwa penyelenggaraan pendidikan inklusi di MTs Yaketunis dapat berjalan dengan baik dengan bekerja sama dengan pemerintah dan juga partisipasi yang besar dari masyarakat. Namun kerjasama dengan pemerintah masih sangat minim terutama terkait dengan bantuan sarana prasarana yang khusus dibutuhkan oleh anakanak tuna netra. Hal ini dikarenakan belum ada payung hukum yang khusus mengatur pendidikan inklusif di madrasah. Bantuan sarana prasarana yang diberikan sama dengan sekolah umum. Namun demikian, dengan berbagai keterbatasan, anak-anak MTs Yaketunis ini banyak menorehkan prestasi baik di bidang akademik maupun non akademik.

Penelitian-penelitian tersebut diatas menjadi informasi penting dalam pengembangan pendidikan inklusif di madrasah dari sisi regulasi dan juga penyelenggaraan. Penelitian ini lebih memfokuskan pada pengelolaan pendidikan inklusif di madrasah yang mencakup pada pengelolaan peserta didik, sarana prasarana, tenaga pendidik, kurikulum, pembiayaan, lingkungan, monitoring dan evaluasi, dan hubungan dengan masyarakat.

\section{METODOLOGI}

Penelitian ini menggunakan pendekatan kualitatif untuk mendeskripsikan suatu proses kegiatan pendidikan berdasarkan apa yang terjadi di lapangan sebagai bahan kajian lebih lanjut untuk menemukenali kekurangan dan kelemahan pendidikan sehingga dapat ditentukan upaya penyempurnaannya. Selain itu juga untuk menganalisis dan menafsirkan suatu fakta, gejala dan peristiwa pendidikan yang terjadi di lapangan sebagaimana adanya dalam konteks ruang dan waktu serta situasi lingkungan pendidikan secara alami. Penelitian ini dilakukan pada bulan September 2018 di 
MTs Yabika Tangerang Banten. Penelitian ini menggali data kualitatif yang dikumpulkan melalui wawancara, khususnya kepada pejabat pengambil kebijakan baik ditingkat pusat maupun daerah dan juga ketua yayasan ataukepala madrasah. Data-data terkait penyelenggaraan pendidikan inklusif juga digali dari para guru, Kepala TU, komite madrasah, pengawas, dan peserta didik.

Metode penelitian yang digunakan adalah metode deskriptif kualitatif. Metode ini digunakan untuk menggambarkan suatu gelaja, peristiwa, dan kejadian yang terjadi pada masa sekarang. Menurut Sukmadinata (2011) penelitian deskriptif memiliki beberapa variasi, diantaranya studi perkembangan: penelitian deskriptif, bisa mendeskriptifkan sesuatu keadaan saja, tetapi bisa juga mendeskriptifkan keadaan dalam tahapan-tahapan perkembangannya. Sedangkan teknik pengumpulan data yang digunakan dalam penelitian ini adalah pedoman wawancara, studi dokumentasi dan observasi. studi dokumentasi digunakan untuk mendapatkan data-data sekunder. sedangkan wawancara diarahkan kepada seluruh responden seperti pejabat kanwil/kemenag kota/kabupaten, ketua yayasan/kepala madrasah, pengawas, komite, orang tua siswa, guru, siswa dan sebagainya. Mereka yang diwawancarai adalah mereka yang dapat dipertimbangkan memenuhi syarat untuk memberikan pandangan dan penilaian terhadap penyelenggaraan pendidikan inklusif di madrasah.Sementara itu metode observasi digunakan untuk pengamatan terhadap objekobjek penelitian yang penting yang akan memperkaya data penelitian.

Teknik analisis deskriptif kualitatif. Analisis deskriptif digunakan untuk menjelaskan secara utuh pengelolaan pendidikan inklusif di madrasah yang didasarkan kepada kriteria-kriteria/indikator tertentu. Pengukuran sejauhmana tujuan pelaksanaan program/kegiatan tercapai digunakan sebagai bahan pertimbangan dalam mengambil suatu kebijakan atau keputusan.

\section{HASIL DAN PEMBAHASAN}

\section{Sejarah berdirinya}

Yayasan Pendidikan Islam Terpadu Bina Insan Kamil (Yabika) yang memiliki jenjang
Raudhaltul Athfal (RA), Madrasah Ibtidaiyah (MI), Madrasah Tsanawiyah (MTs) dan Madrasah Aliyah (MA) ini beralamat di Jl. Raya Perum ASABRI Ds. Kutruk Kec. Jambe Kab. Tangerang Prov. Banten. Yabika sebagai salah satu lembaga pendidikan di wilayah Kecamatan Jambe Kab. Tangerang Provinsi Banten yang mempunyai nilai historis yang besar, tidak bisa dipisahkan dengan Pendirinya yaitu Drs. H.M. Agus Salim, M.Pd. Pada tanggal 13 Juli 2009 Drs. H.M. Agus Salim, M.Pd membangun yayasan yang kemudian lebih dikenal dengan Yabika telah banyak memberikan konstribusi dan sumbangan kepada masyarakat luas baik dalam bidang pendidikan, pengabdian kepada masyarakat.

Keberadaan unit-unit pendidikan di
tengah-tengah kehidupan masyarakat
memberikan arti tersendiri, yaitu sebagai
manifestasi nilai-nilai pengabdian dan
perhatian kepada masyarakat sekitarnya. Kepercayaan dan perhatian masyarakat luas terhadap keberadaan Yabika adalah dasar kemajuan dan perkembangan di masa depan, dengan tetap mengembangkan visi dan misi pendidikan yang mandiri serta peningkatan kualitas pendidikan masyarakat.

Motto dari MTs Yabika ini adalah Cerdas Intelektual, cerdas emosional, cerdas spiritual. Adapun visi madrasah ini adalah Mewujudkan lulusan yang berbudi, berakhlak mulia, berbudaya cerdas dan mandiri berbasis imtaq dan berwawasan lingkungan.

Sebelum MTs Yabika menjadi salah satu pilot project madrasah inklusif tahun 2015, madrasah ini sudah menerima anak yang berkebutuhan khusus. Yayasan menerima ABK saat itu karena banyak orangtua siswa yang datang dan berkeinginan menitipkan anaknya di Yabika. Mereka beralasan bahwa tidak ada sekolah yang mau menerima anak mereka dan untuk bersekolah SLB lokasinya cukup jauh dan biayanya besar. Akhirnya pihak yayasan membuat satu kebijakan untuk untuk menerima semua $\mathrm{ABK}$ yang mau masuk ke madrasah ini dari jenjang RA sampai MA. Dasar kebijakan yayasan adalah Peraturan Menteri Agama (PMA) Nomor 90 Tahun 2013 tentang Penyelenggaraan Pendidikan Madrasah yang menyebutkan bahwa madrasah wajib menyediakan akses bagi peserta didik 
berkebutuhan khusus. Atas dasar itu mulai tahun 2013 Yabika menerima ABK untuk belajar di madrasah ini.

Pada tahun 2015, MTs Yabika ditunjuk sebagai salah satu madrasah dari 22 madrasah yang menjadi piloting project oleh Direktorat Jenderal Pendidikan Islam Kementerian Agama yang bekerjasama dengan USAID. Ditunjuknya MTs Yabika ini karena madrasah ini sebelumnya sudah menyelenggarakan pendidikan bagi ABK dan dianggap layak menjadi proyek percontohan penyelenggaraan pendidikan inklusi di madrasah. SK Penetapan MTs Yabika dari Dirjen Pendidikan Islam Kementerian Agama RI sebagai madrasah inklusif tertuang dalam Surat Keputusan Jenderal Pendidikan Islam Nomor 3211 Tahun 2016 tentang Penetapan 22 Madrasah Inklusif.

Pengelolaan pendidikan inklusif bagi siswa difabel mencakup perencanaan, pelaksanaan, pengawasan, pelaporan, dan pertanggungjawaban yang meliputi komponen kurikulum, proses dan hasil pembelajaran, administrasi dan manajemen satuan pendidikan, organisasi kelembagaan satuan pendidikan, sarana dan prasarana, ketenagaan, pembiayaan (dalam bentuk Rencana Kegiatan dan Anggaran Sekolah), peserta didik, peran serta masyarakat, dan lingkungan sekolah.

Perencanaan terkait penyelenggaraan pendidikan inklusif di MTs Yabika sudah dilakukan dan tertuang dalam Rencana Kerja Madrasah (RKM). Perencanaan ini terkait dengan semua komponen-komponen yang dibutuhkan dalam penyelenggaraan pendidikan inklusif. Dalam RKM 2015, MTs Yabika akan menyusun Program Pembelajaran Individual (PPI) dan sekarang sudah tersusun PPI tersebut. Silabus dikembangkan sesuai dengan perkembanagn ABK (modifikasi silabus), Modifikasi Rencana Pelaksanaan Pembelajaran (RPP), Pelatihan penyususnan RPP regular dan ABK. Dalam hal ketenagaan perencanaan dikhususkan dalam menyiapkan guru khusus pendamping ABK. Terkait sarana dan prasarana, madrasah juga melengkapi kekurangan ruang kelas dan ruang lainnya dan disesuaikan dengan kebutuhan $\mathrm{ABK}$, membuat bidang miring, renovasi toilet untuk $\mathrm{ABK}$, kursi roda, dan emdia pembelajaran. Dalam hal pembiayaan $\mathrm{ABK}$, yayasan berupaya untuk mendapatkan tambahan dukungan pembiayaan yang diperuntukkan beasiswa bagi siswa tidak mampu, siswa berprestasi dan juga $\mathrm{ABK}$.

Dari 13 ABK di madrasah ini, terdapat 4 anak dengan kategori lamban belajar (slow learner), 3 ABK dengan gangguan perkembangan perilaku (emosi meledak-ledak), dan 2 ABK dengan gangguan kesulitan membaca khususnya dalam Bahasa Arab, 3 ABK mengalami gangguan penglihatan (1 $\mathrm{ABK}$ dengan gangguan penglihatan jarak jauh dan 2 ABK dengan gangguan penglihatan ringan (low vision)), dan $1 \mathrm{ABK}$ dengan hambatan kaki.

Langkah awal yan dilakukan pada awal penerimaan siswa adalah indentifikasi dan assesmen anak. Pada saat ABK melakukan pendaftaran akan dilakukan identifikasi. Identifikasi adalah proses untuk mengenali keragaman siswa. Madrasah penyelenggara pendidikan inklusi memiliki peserta didik yang berkebutuhan khusus. Untuk mengetahui kondisi peserta didik yang berkebutuhan khusus tersebut perlu dilakukan identifikasi. Di MTs Yabika, identifikasi peserta didik dilakukan pada saat pendaftaran awal tahun pelajaran. Pada tahun 2015 identifikasi ini dilakukan oleh panitia PPDB dan Kesiswaan yang difasilitasi Madrasah Development Center (MDC) dengan mendatangkan psikolog dari Untirta. Yabika juga bekerjasama dengan puskesmas dinkes. Namun pada tahun berikutnya jika ada $\mathrm{ABK}$ yang ingin masuk ke MTs Yabika maka identifikasi dilakukan pada saat awal pendaftaran dengan mewawancarai orang tua/wali terkait kondisi siswa baru. Identifikasi ini dilakukan oleh panitia penerimaan siswa baru yang ditunjuk oleh Yabika.

Setelah proses identifikasi anak dilakukan, tahap selanjutnya adalah assesmen. Assesmen adalah proses untuk mengidentifikasi kelebihan, kekurangan dan kebutuhan peserta didik terutama peserta didik berkebutuhan khusus. Assessmen terhadap ABK dilakukan pada awal tahun ketika anak mau belajar di MTs Yabika. Pada awal tahun pelajaran 2015/2016 assesmen dilakukan bersama dengan tim dari MDC dan juga psikolog dari Untirta. Teknik assesmen yang digunakan berupa tes non formal dengan 
menggunakan serangkaian alat asesmen yang tidak baku yaitu pedoman observasi, pedoman wawancara, dan pedoman analisis. Alat assesmen ini disusun oleh tim MDC dan panitia Yabika (kepala madrasah dan wakil, guru kelas, guru mata pelajaran, dan guru pembimbing khusus). Aspek assesmen anak disabilitas mencakup hal-hal sebagai berikut: (1) identitas anak; (2) identitas keluarga; (3) dimensi biologis; (4) dimensi kognisi; (5) dimensi psikologis; (6) dimensi sosial; (7) dimensi spiritual; (8) minat dan potensi anak dengan disabilitas; (9) perlindungan anak dengan disabilitas; (10) kesimpulan assesmen; (11) kebutuhan utama anak dengan disabiltas.

Dalam proses pembelajaran, ABK ditempatkan dikelas bersama dengan anakanak regular satu kelas dengan anak-anak regular tapi tingkat kompetensinya yang paling rendah dibanding yang lain. Kepala MTs Yabika, Dadan Mardiana, mengatakan bahwa pemetaan kelas ini bertujuan untuk memudahkan guru dalam proses pembelajaran karena siswa dalam satu kelas memiliki tingkat kompetensi yang tidak jauh berbeda. Hal ini sejalan yang dikatakan Adodo and Agbayewa (2011), bahwa pengelompokkan siswa berdasarkan kemampuan kognitif dapat memberikan keuntungan yakni meningkatan prestasi siswa, memudahkan guru dalam mengajar di kelas, memudahkan guru untuk mengendalikan proses pemberian instruksi, dan memudahkan guru memberikan penguatan kepada siswa yang berprestasi tinggi dan berprestasi rendah, siswa yang berprestasi rendah merasa lebih nyaman ketika berada bersama teman-teman yang memiliki kemampuan setara, siswa yang berprestasi tinggi juga dapat saling menjaga dan mendukung minat mereka, siswa bisa saling menghargai dan berpartisipasi dalam kerja kelompok antar siswa, membantu guru dalam menyesuaikan bahan dan metode pengajaran yang sesuai dengan kebutuhan dan tingkat siswa, pemanfaatan waktu, ruang dan bahan bagi siswa dapat menjadi lebih optimal, dan siswa dapat bekerja secara cepat atau lambat sesuai dengan tingkat kemampuan kelas mereka.

Dalam penyelenggaraan pendidikan inklusif, hal yang juga dianggap penting adalah pengelolaan tenaga pendidik, khususnya Guru Pembimbing Khusus (GPK) yang bertugas membantu tenaga pendidik lainnya untuk menyelengarakan pendidikan inklusif. GPK di sekolah inklusif menjadi salah satu faktor keberhasilan karena dapat memperkuat dan memperkokoh penyelenggaraan program pendidikan inklusif. Menurut Direktorat PLB (2007), seorang guru pembimbing khusus atau guru pendidikan khusus tidak hanya memerlukan 4 (empat) kompetensi utama yang harus dimiliki oleh para guru pada umumnya tetapi juga harus memiliki kompetensi khusus yang digunakan untuk menangani $\mathrm{ABK}$, yaitu: (1) kemampuan umum yaitu kemampuan yang diperlukan untuk mendidik peserta didik pada umumnya (2) kemampuan dasar (basic ability) yaitu kemampuan yang diperlukan untuk mendidik peserta didik berkebutuhan khusus, dan (3) kemampuan khusus yaitu kemampuan yang diperlukan untuk mendidik peserta didik kebutuhan khusus jenis tertentu (spesialis). Dengan kompetensi yang dimiliki, anak-anak dengan kebutuhan khusus tersebut dapat terlayani dengan baik dan hasil yang dicapai juga lebih maksimal.

Walaupun keberadaannya sangat penting namun ternyata tidak semua sekolah inklusif memiliki GPK. Guna mengatasi permasalahan yang ditimbulkan akibat tidak tersedianya GPK di sekolah penyelenggara pendidikan inklusif, sebagaimana yang tercantum dalam Pedoman Tendik (2007) adalah dengan melakukan perekrutan GPK yang dapat dilakukan dengan tiga alternatif yaitu: pertama, melalui kerjasama guru SLB terdekat; kedua, merekrut guru dengan kualifikasi PLB dan guru reguler yang memperoleh pelatihan tentang ABK; dan ketiga, dari klinik-klinik pendidikan atau pusat pengembangan anak.

Kepala MTs Yabika, Dadan Masdiana, mengatakan bahwa penyiapan tenaga pendidik untuk ABK menjadi salah satu prioritas dalam menangani $\mathrm{ABK}$, terutama $\mathrm{ABK}$ dengan gangguan emosi dan perilaku. Hal ini tertuang dalam program yang telah disusun dalam RKM. Saat ini MTs Yabika memiliki 3 GPK. Guru-guru tersebut merupakan guru regular yang diberikan pelatihan tentang $\mathrm{ABK}$. Jadi mereka selain mengajar anak-anak di kelas regular, mereka juga diberikan tugas untuk 
memberikan pendampingan pada ABK terutama anak-anak yang memiliki gangguan emosi dan perilaku, pendampingan belajar diberikan secara individual.

Pelatihan bagi guru-guru penyelenggara inklusif sangat dibutuhkan. Pelatihan ini sangat membantu guru-guru regular atau pemula untuk lebih memiliki kesiapan dalam menghadapi ABK. Bukan hanya GPK tapi semua guru penting untuk memahami kebutuhan ABK dalam pembelajaran. Untuk itu Yayasan Yabika mengadakan pelatihan khusus untuk guru-guru dalam menangani ABK dan juga telah melakukan workshop untuk modifikasi kurikulum khusus ABK.

Pada dasarnya dalam pelaksanaan pembelajaran pendidikan inklusif, kurikulum disesuaikan dan fleksibel sesuai kebutuhan ABK. Kurikulum fleksibel adalah yang mengakomodasi peserta didik dengan berbagai latar belakang kemampuan dengan cara eskalasi, duplikasi, modifikasi, omisi, dan subsitusi (Kustawan, 2013). Artinya hal yang penting untuk dilakukan adalah penyesuaian kurikulum dengan menekankan pada pemenuhan kebutuhan belajar yang disesuaikan dengan kemampuan anak. Perumusan kurikulum yang fleksibel oleh sekolah tidak bisa berjalan sendiri, melainkan memerlukan kerjasama antara guru dengan GPK, orang tua, para professional dan anak.

Untuk beberapa $\mathrm{ABK}$ dengan kategori ringan, para tenaga pendidik MTs Yabika tetap menggunakan model kurikulum umum, karena mereka menganggap bahwa setiap ABK dengan berbagai jenis kebutuhannya mampu mengikuti semua mata pelajaran dan tingkat kesulitan yang sama dengan peserta didik lainnya, namun pembelajarannya akan menyesuaikan dengan kebutuhan khusus ABK tersebut. Artinya, secara normatif model kurikulum yang digunakan tidak mengalami penyesuaian, baik berupa modifikasi maupun individualisasi, namun kurikulum fleksibel akan terlihat ketika pembelajaran berlangsung di kelas regular. Untuk ABK dengan gangguan emosi dan perilaku memang tidak bisa menggunakan kurikulum regular seperti anakanak lainnya karena memang dianggap tidak mampu mengikuti materi tersebut. Walaupun sudah masuk jenjang MTs namun ABK kategori ini masih memiliki kemampuan pembelajaran yang setara dengan MI/SD sehngga perlu perlakuan pembelajaran khusus yaitu PPI.

Para guru yang mengajar di MTs Yabika selalu melibatkan GPK dalam proses pembelajaran, baik secara langsung maupun tidak langsung. Hal ini dapat ditunjukkan dengan adanya pemberian perlakuan khusus untuk mata pelajaran tertentu, pendampingan proses pembelajaran dan ujian, dan pemberian motivasi terhadap siswa difabel.

Sebagaimana layaknya sekolah umum, sekolah inklusif memiliki sarana dan prasarana yang sama dengan sekolah lainnya seperti ruang kelas, ruang guru dan kepala sekolah, ruang tata usaha, ruang praktek/laboratorium, perpustakaan, ruang bimbingan konseling, UKS, tempat ibadah, kantin, lapangan olah raga, dan sebagainya. Komponen sarana dan prasarana dalam sistem pendidikan inklusif, menjadi salah satu komponen yang penting. Dengan melihat karakteristik ABK, maka sarana dan prasarana pendidikan yang dibutuhkan tentunya menyesuaikan dengan kebutuhan anak. Selain komponen sekolah seperti tanah, gedung, kantor, gedung sekolah, laboratorium, monumen, tempat tinggal dan sebagainya, diperlukan pula sarana prasarana khusus yang dibutuhkan oleh ABK. Untuk $\mathrm{ABK}$ dengan gangguan penglihatan ringan (low vision), diperlukan alat untuk membantu memperjelas penglihatannya seperti alat bantu magnifier lens set, CCTV, view scan, televisi, prisma monocular, dll.

Untuk anak yang mengalami kesulitan belajar diperlukan ruang untuk melaksanakan kegiatan pembelajaran dan penilaian. Jadi madrasah memiliki satu ruang sumber untuk kegiatan $\mathrm{ABK}$ tersebut. Untuk anak dengan kecacatan pada fisik, diperlukan alat untuk mobilitas seperti kursi roda dan juga akses jalan yang memudahkan. Pembelajaran dilaksanakan di ruang belajar lantai satu. Untuk mobilitas anak yang mengalami gangguan penglihatan juga perlu disiapkan akses jalan dengan menggunakan guiding block.

Sekolah penyelenggara pendidikan inklusif membutuhkan dana tambahan untuk biaya operasional. Biaya tambahan digunakan 
untuk pengadaan dan pemeliharaan sarana dan prasarana tambahan, gaji/honor guru pembimbing khusus, biaya konsultasi dengan terapis atau psikolog, biaya pengadaan alat-alat bantu atau media pembelajaran dan lain sebagainya. Pada sisi proses pembelajaran dan pengelolaan aspek manajerial lainnya dapat dilakukan secara inklusif. Namun dari sisi pengelolaan keuangan, sekolah-sekolah penyelenggara pendidikan inklusif belum bisa melakukan secara inklusif sehingga beban orang tua dengan anak $\mathrm{ABK}$ lebih besar dibanding dengan anak normal lainnya.

MTs Yabika membuat alokasi dana khusus untuk penyelenggaraan pendidikan inklusif. Dana tersebut digunakan untuk pengadaan fasilitas pendidikan inklusif seperti pembuatan bidang miring, toilet, kursi roda, pembuatan guiding block, dan media pembelajaran khusus ABK. Selain itu dana juga disediakan untuk pengadaan guru yang memiliki kompetensi khusus menangani ABK atau juga untuk mengadakan workshop atau pelatihan guru pembimbing khusus bagi $\mathrm{ABK}$.

Secara umum sumber dana untuk penyelenggaraan pendidikan inklusif berasal dari sumber yang sama dengan pendidikan untuk anak-anak regular lainnya yaitu dari dana dana bantuan Pemerintas pusat yaitu Bantuan Operasional Sekolah (BOS), Dana bantuan Pemerintah Daerah (APBD), dan juga iuran orang tua siswa. Setiap bulan siswa membayar sebesar Rp 50.000 secara khusus untuk bantuan penyelenggaraan pendidikan inklusif, madrasah mendapat bantuan blokgrand tahun 2015 untuk sarana pendukung pendidikan inklusif.

Kegiatan pembinaan, pengawasan dan evaluasi dalam penyelenggaraan pendidikan inklusif di MTs Yabika dirasa masih sangat kurang khususnya dari unsur terkait seperti pengawas kemenag, Pemerintah daerah dan pemerintah pusat sehingga pelaksanaan madrasah inklusif diselenggarakan dengan pemahaman madrasah sendiri sehingga terkesan stagnan. Miskinnya pengawasan ini berakibat pada lemahnya evaluasi terlebih saat ini tidak ada siswa $\mathrm{ABK}$ sehingga nyaris pembinaan inklusif terabaikan.

Saat ini pengawasan dari pengawas di kemenag pun belum menyentuh penyelenggaraan madrasah inklusif bahkan terkadang ada yang belum memahami bagaimana pengelolaan pendidikan inklusif di madrasah. Sebagai contoh MTs Yabika memiliki 1 orang siswa yang secara kemampuan belajar jauh dari standar minimal bahkan kompetensinya harus diturunkan levelnya sampai kembali ke level MI, namun karena yang bersangkutan masuk ke MTs dengan membawa ijazah SD maka dengan segala keterbatasannya MTs ini tetap berusaha untuk menerima.

Kepala madrasah selaku ujung tombak pelaksanaan madrasah inklusi sangat membutuhkan regulasi yang jelas dari kemenag sehingga pelaksanaan pendidikan inklusif madrasah benar-benar dapat berjalan optimal. Sementara kemitraan dengan dinas pendidikan yang notabene telah memiliki sekolah inklusi yang sudah berjalan lebih baik belum terjembatani. Ini akan berdampak pada sulit berkembangnya pendidikan inklusif di madrasah.

Sekolah penyelenggara pendidikan inklusif dapat melibatkan masyarakat dalam perencanaan, penyediaan tenaga ahli terkait, pengambilan keputusan, pelaksanaan pembelajaran dan evaluasi, pendanaan, pengawasan, penyaluran lulusan, dan lain sebagainya. Pelibatan masyarakat tersebut dapat diakomodasikan melalui komite sekolah, dewan pendidikan, Persatuan Orangtua Murid (POM), atau melalui forum-forum pemerhati pendidikan.

MTs Yabika melalui komite madrasah sudah mensosialisasikan program-program pendidikan termasuk penyelenggaraan pendidikan inklusif. Sejak saat itu banyak orang tua siswa yang mendaftarkan anaknya yang memiliki kebutuhan khusus. Semua ABK yang terdaftar diterima belajar di MTs ini. Terhitung sejak tahun 2015 ada 13 ABK yang masuk ke MTs ini.

Kerjasama dalam pengelolaan pendidikan inklusif dilakukan baik dengan pihak internal maupun eksternal. Kerjasama internal dalam lingkungan MTs Yabika cukup baik. Antara pengurus yayasan, kepala madrasah, guru dan tenaga administrasi, peserta didik, pengawas madasah, dan komite madrasah bersinergi untuk memajukan 
madrasah. Yayasan membuat kebijakan untuk penyelenggaraan pendidikan inklusi di MTs Yabika dengan memberikan dukungan anggaran maupun semangat untuk menjalankan pendidikan inklusif. Penganggaran khusus pendidikan inklusif tertuang dalam Rencana Anggaran Pendapatan dan Belanja Madrasah (RAPBM) baik untuk penyediaan sarana prasarana dan fasilitas pembelajaran $\mathrm{ABK}$ maupun untuk peningkatan kualitas guru yang menangani ABK. Kepala madrasah sebagai pimpinan madrasah yang mengimplementasikan pendidikan inklusif menyambut baik kebijakan yayasan. Hal ini terlihat dari rencana kerja madrasah yang disusun oleh kepala madrasah bersama para guru. Dewan guru juga semangat dan sabar dalam membimbing siswa yang berkebutuhan khusus sesuai dengan mata pelajaran masingmasing. Orang tua siswa yang diwakili oleh komite madrasah juga mendukung kebijakan yayasan dalam penyelenggaraan pendidikan inklusif di MTs Yabika.

Namun untuk pengembangan pendidikan inklusif, keterlibatan pengawas madrasah masih minim atau bisa dikatakan tidak ada. Hal ini dikerenakan ketidakpahaman pengawas atau ketidaktahuan tentang penyelenggaraan pendidikan inklusi dimadrasah. Padahal peran pengawas dalam penyelenggraan pendidikan inklusif di madrasah sangat besar. Pengawas mempunyai tanggungjawab untuk mengawasi jalannya semua program madrasah dan mengontrol jalannya pelaksanaan pendidikan inklusif dalam setiap program dan kegiatan yang dilaksanakan oleh madrasah. Pengawas juga seharusnya memberikan penjelasan dan pendampingan kepada guru dan kepala madrasah terkait dengan regulasi dan kebijakan madrasah penyelenggara pendidikan inklusif. Namun karena kebijakan pemerintah terkait penyelenggaraan pendidikan inklusif di madrasah belum jelas dan belum ada payung hukumnya, maka para pengawas juga merasa tidak memiliki tanggungjawab itu.

Kerjasama eksternal MTs Yabika dengan pihak luar hanya dilakukan pada saat awal tahun 2015 dimana madrasah ini menjadi salah satu madrasah piloting penyelenggraan pendidikan inklusif. Kerjasama ini dilakukan dengan pihak MDC dalam bentuk pendampingan. Kerjasama juga dilakukan dengan Untirta dan SLB Serang terkait dengan pelatihan-pelatihan untuk guru-guru yang akan mengajar ABK. Pelatihan diberikan hanya pada awal program piloting madrasah inklusif tahun 2015 yang diselenggarakan oleh MDC yang bekerja sama dengan Untirta. Setelah 6 bulan berjalan program tersebut dilepas untuk bisa berjalan secara mandiri. Sampai saat ini pemerintah baik pusat maupun daerah juga belum pernah memberikan pelatihan-pelatihan terkait penyelenggaraan pendidikan inklusi madrasah. Yabika juga belum menjalin kerjasama secara intens dengan pihak luar seperti pusat-pusat sumber yang memberikan konsultasi dan layanan pendukung bagi madrasah penyelenggara pendidikan inklusif, dunia usaha dan industri, perguruan tinggi, para profesional (psikolog, dokter, terapis, dll), pemerintah, serta LSM.

\section{PENUTUP}

Penyelenggaraan pendidikan inklusif di MTs Yabika secara umum sudah berjalan dengan cukup baik. Pengelolaan ABK sudah disesuaikan dengan kebutuhannya baik fasilitas ABK, sarana prasarana, kurikulum, pembelajaran maupun sistem penilaiannya. Madrasah juga sudah menyediakan GPK bagi ABK. Namun demikian semua pemenuhan kebutuhan ABK, GPK, dan fasiltas pembelajarannya masih disesuaikan dengan kemampuan Yabika. Oleh karena itu, penyelenggaraan pendidikan inklusif di MTs Yabika belum seperti standar yang diharapkan.

Pada beberapa aspek dalam pengelolaan pendidikan inklusif juga belum berjalan sebagaimana mestinya. Penerimaan ABK baru tidak melalui assesmen dan identifikasi yang sesuai panduan tetapi hanya menggunakan tes dan wawancara dengan orang tua siswa dan masih banyak guru yang belum mendapatkan pelatihan dalam menangani ABK. Pembinaan, pengawasan, dan evaluasi dari pengawas dan kemenag juga belum ada. Demikian juga kerjasama eksternal juga belum banyak dilakukan oleh MTs Yabika.

Dari kesimpulan diatas, penelitian ini menghasilkan beberapa rekomendasi: Pertama, MTs Yabika perlu meningkatkan layanan pendidikan untuk anak-anak berkebutuhan 
khusus dengan menjalin kerjasama dengan pihak luar seperti dunia usaha dan industri, para professional (psikolog, dokter, therapis, dll), LSM, dll. Kedua, pemerintah (kementerian agama) untuk serius mengembangkan pendidikan inklusif di madrasah dengan membuat peraturan khusus (payung hukum) tentang penyelenggaraan pendidikan inklusif di madrasah.

\section{UCAPAN TERIMA KASIH}

Terima kasih kepada Kepala Puslitbang Pendidikan Agama dan Keagamaan Badan Litbang dan Diklat yang telah memberi kesempatan kepada penulis untuk meneliti, Dewan Pembinan dan Pengurus Yayasan Yabika Tangerang, Kepala dan Wakil Kepala MTs dan MA Yabika Tangerang, guru dan Kepala Tata Usaha MTs Yabika Tangerang yang turut membantu memberikan data dan informasi, juga kepada Redaktur Edukasi atas termuatnya tulisan ini. Semoga tulisan ini memberikan wawasan dalam pendidikan agama di Indonesia.

\section{DAFTAR PUSTAKA}

Adodo, S. O. and Agbayewa, J. O. (2011) Effect of homogenous and heterogeneous ability grouping class teaching on students interest, attitude and achievement in integrated science, International Journal of Psychology and Counselling, 3(3), pp. 48-54.

Arikunto, S. (1988) Pengelolaan Siswa dan Kelas (Sebuah Pendekatan Evaluatif). Jakarta: CV Rajawali.

Direktorat Pembinaan Sekolah Luar Biasa. (2008) Pengadaan dan pembinaan tenaga kependidikan dalam pendidikan inklusif. Direktorat Jenderal Manajemen Pendidikan Dasar dan Menengah Departemen Pendidikan Nasional.

Djamarah, S. B. and Zain, A. (2006) Strategi belajar mengajar. Jakarta: Rineka Cipta.

Garnida, D. (2015) Pengantar Pendidikan Inklusif. Bandung: Refika Aditama.

Kustawan, D. (2013) Manajemen pendidikan inklusif. Jakarta: Luxima Metro Media.
Mi'raj Islamic News Agency (MINA) (2017) 'Anak Kebutuhan Khusus di Indonesia Capai 1,6 Juta', 5 February. Available at: $\quad$ https://minanews.net/anakkebutuhan-khusus-di-indonesia-capai16-juta/.

Mudjito, A., Harizal and Elfindri (2012) Mudjito, Harizal, dan Elfindri. 2012. Pendidikan Inklusif. Tuntunan untuk Guru, Siswa, dan Orang Tua Anak Berkebutuhan Khusus dan Layanan Khusus. Disertai Tuntunan untuk Pemda dan Yayasan Pendidikan. Jakarta: Baduose Media. Jakarta: Mudjito, Harizal, dan Elfindri. 2012. Pendidikan Inklusif. Tuntunan untuk Guru, Siswa, dan Orang Tua Anak Berkebutuhan Khusus dan Layanan Khusus. Disertai Tuntunan untuk Pemda dan Yayasan Pendidikan. Jakarta: Baduose Media.

Sholikhah, R. M. (2016) Pendidikan Inklusif di Kementerian Agama (Studi di Madrasah Ibtidaiyah Ma'arif Giriloyo 2 dan Madrasah Ibtidaiyah YAPPI Balong). Uin Sunan Kalijaga Yogyakarta. Available at: http://digilib.uinsuka.ac.id/id/eprint/22720.

Sukmadinata, N. S. (2011) Metode Penelitian Pendidikan. Bandung: PT Remaja Rosdakarya.

Suryati, A. E. and Haryanto, S. (2016) Evaluasi pelakasanaan program pendidikan inklusif di Madrasah Aliyah Negeri Maguwoharjo Yogyakarta, Wiyata Dharma: Jurnal Penelitian dan Evaluasi Pendidikan, 4(2), pp. 187-193. doi: 10.30738/WDPEP.V4I2.2277.

Tangsel Pos. (2016) 'Banten Minim Sekolah untuk Anak Berkebutuhan Khusus', 25 April. Available at: http://tangselpos.co.id/2016/04/25/bante n-minim-sekolah-anak-berkebutuhankhusus/.

Tarmansyah, S. (2007) Inklusi: Pendidikan Untuk Semua. Jakarta: Departemen Pendidikan dan Kebudayaan RI. 